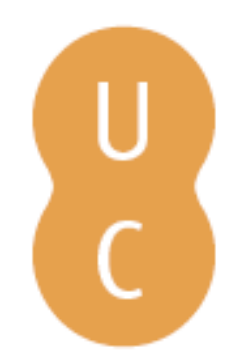

\title{
nommalina
}

\section{Economia solidária, inovação social, empreendorismo e desenvolvimento local}

Autor(es): $\quad$ Ramos, Maria da Conceição Pereira

Publicado por: Imprensa da Universidade de Coimbra

URL

persistente: $\quad$ URI:http://hdl.handle.net/10316.2/31291

DOI: $\quad$ DOI:http://dx.doi.org/10.14195/978-989-26-0228-8_22

Accessed : $\quad$ 26-Apr-2023 11:40:07

A navegação consulta e descarregamento dos títulos inseridos nas Bibliotecas Digitais UC Digitalis, UC Pombalina e UC Impactum, pressupõem a aceitação plena e sem reservas dos Termos e Condições de Uso destas Bibliotecas Digitais, disponíveis em https://digitalis.uc.pt/pt-pt/termos.

Conforme exposto nos referidos Termos e Condições de Uso, o descarregamento de títulos de acesso restrito requer uma licença válida de autorização devendo o utilizador aceder ao(s) documento(s) a partir de um endereço de IP da instituição detentora da supramencionada licença.

Ao utilizador é apenas permitido o descarregamento para uso pessoal, pelo que o emprego do(s) título(s) descarregado(s) para outro fim, designadamente comercial, carece de autorização do respetivo autor ou editor da obra.

Na medida em que todas as obras da UC Digitalis se encontram protegidas pelo Código do Direito de Autor e Direitos Conexos e demais legislação aplicável, toda a cópia, parcial ou total, deste documento, nos casos em que é legalmente admitida, deverá conter ou fazer-se acompanhar por este aviso. 


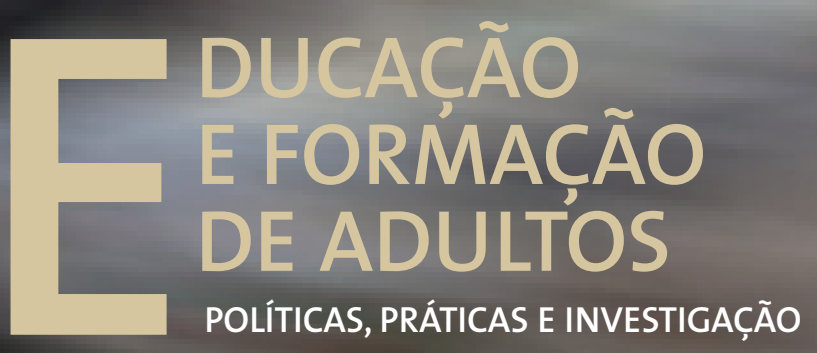

Luís Alcoforado • Joaquim Armando G. Ferreira António Gomes Ferreira • Margarida Pedroso de Lima Cristina Vieira • Albertina L. Oliveira • Sónia Mairos Ferreira 


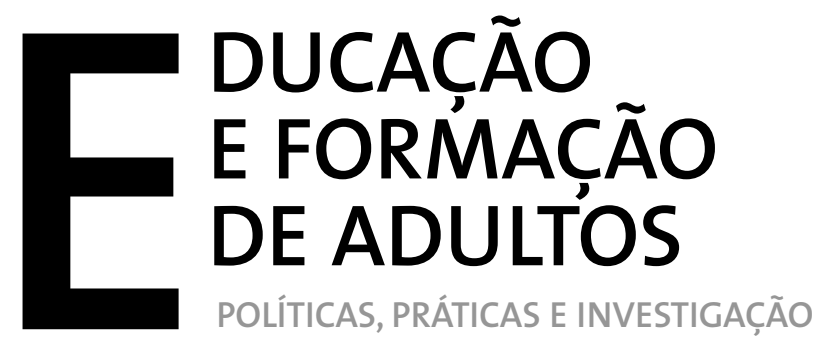

Luís Alcoforado • Joaquim Armando G. Ferreira António Gomes Ferreira - Margarida Pedroso de Lima Cristina Vieira • Albertina L. Oliveira • Sónia Mairos Ferreira 
EDIÇÃo

Imprensa da Universidade de Coimbra

URL: http://www.uc.pt/imprensa_uc

Vendas online: http://www.livrariadaimprensa.com

CONCEPÇÃO GRÁFICA

António Barros

Pré-Impressáo

SerSilito-Empresa Gráfica, Lda

EXECUÇÃo GRÁFICA

SerSilito-Empresa Gráfica, Lda

ISBN

978-989-26-0136-6

DePósito LEgaL

$340309 / 12$ 



\section{ECONOMIA SOLIDÁRIA, INOVAÇÃO SOCIAL, EMPREENDEDORISMO E DESENVOLVIMENTO LOCAL}

Maria da Conceição Pereira Ramos

Universidade do Porto

Cada um esconde dentro de si mesmo mais do que aquilo que alguma vez poderá explorar.

A não ser que criemos as condiçōes que nos permitam descobrir os limites do nosso potencial, nunca saberemos o que vai dentro de nós.

Muhammad Yunus Fundador do microcrédito e prémio Nobel da Paz, 2006.

\section{Economia solidária, crise do trabalbo e do estado-providência - novo paradigma económico alternativo ao capitalismo?}

O modelo actual de desenvolvimento económico, assente na competitividade, coloca novos desafios à construção de uma sociedade inclusiva e à reestruturação dos modelos de protecção e de direitos sociais (Castles, 2004). A partir da segunda metade da década de setenta, do século XX, começa a agravar-se na Europa, a instabilidade do emprego e a extensão do desemprego de longa duração. As transformaçóes ocorridas na economia implicaram crescente segmentação do mercado de trabalho, multiplicidade de modalidades de integração laboral precárias e atípicas e acréscimo das desigualdades e das discriminaçóes (OCDE, 2008). A globalização e a natureza sistémica da crise condicionam as prioridades de acção do Estado-nação em domínios tradicionais da política social, como o emprego e a protecção social, colocando-se o desafio da manutenção dos níveis de protecção, dadas as restriçóes de financiamento.

Náo obstante o facto dos regimes de segurança social se apresentarem actualmente de forma mais completa, há situações humanas e sociais concretas que não se enquadram nos mecanismos do seu funcionamento. É neste contexto que a acção social visa colmatar lacunas dos regimes e potenciar a sua eficácia e humanização (Ramos, 2003). Os serviços de acção social prestados por instituiçóes públicas e privadas, procuram prevenir ou auxiliar situaçóes de exclusão, disfunção ou doença, apoio à família e resposta a novos problemas sociais. A coberto das razóes associadas ao financiamento e à sustentabilidade da segurança social, tem-se assistido, na Europa, a uma forte pressão para a desregulamentação dos sistemas sociais e à diminuição da intervenção do Estado na protecção social com o objectivo de redução da despesa pública, diminuindo as prestaçóes do regime contributivo e privatizando-se algumas das suas componentes. A precarização de alguns grupos da população, devido à instabilidade laboral e à redução dos níveis de protecção dos sistemas sociais, provoca a 
necessidade da acção social. As políticas de protecção social, apesar de todas as pressóes contraditórias, são um instrumento importante de salvaguarda dos direitos de cidadania e de coesão social (Esping-Andersen, 2002).

Como identificar a relação entre economia social e o modelo económico actual? Constitui esta economia um ajustamento ou alternativa à sociedade de mercado? A economia solidária é apontada como uma resposta ao agravamento da crise do trabalho e à crescente insatisfaçáo com o desempenho do sistema público de segurança social. Para alguns autores, a economia social pode desempenhar um papel essencial na resolução dos problemas sociais gerados pelo modelo económico vigente (Ramos, 2011). Os limites deste modelo decorrem de múltiplos factores, entre os quais: agravamento do fosso entre países ricos e países periféricos, sem acesso à satisfação das necessidades básicas; marginalização, exclusão social e desigualdades crescentes e persistentes no interior dos países ricos, constituindo uma ameaça à coesão social; enfraquecimento do poder das instituições políticas nacionais, face à orientação das suas economias no sentido do bem-estar dos cidadãos e da prossecução da solidariedade.

A crise torna visível o mito da auto-regulação do mercado, mas também o facto do capitalismo gerar desigualdades, instabilidades, ineficiências, e ser ecologicamente insustentável. Gerir para a sustentabilidade é cada vez mais um imperativo de competitividade e a busca do desenvolvimento sustentável nos seus três pilares - económico, sócio-cultural e ambiental - tornou-se uma preocupação a nível mundial (Ramos, 2008, 2009). Podemos qualificar de sustentável todo o processo de transformação humana ou material que garante reproduçâo, sobrevivência e melhor qualidade de vida num horizonte temporal longo. Por isso, a economia terá que ser sustentável, o social é um dos seus atributos intrínsecos, de modo a gerir, permanentemente, a inclusão.

A economia solidária, nas suas diferentes vertentes, surge como uma forma de resistência ao modelo económico dominante e a sua expansão nas sociedades modernas constitui um terceiro sector da economia, a par do sector mercantil e do sector público, dotado de características específicas. A designação de "terceiro sector" prende-se com o facto de fazer apelo a dois tipos de recursos: é criado por iniciativa privada, mas recebe financiamento e orientaçóes do Estado.

Com a economia social ou solidária (cooperativas, grupos de consumo responsável, banca ética...), assiste-se à expansão de iniciativas económicas diferentes das capitalistas, demonstrando que existem outras formas de produção, consumo e financiamento, regidas por lógicas democráticas, sustentáveis e solidárias (Santos, 2003). Estas iniciativas constituem embriôes de uma economia mais justa, democrática e sustentável, com produção e distribuição de bens e serviços necessários a uma vida digna, tendo em conta as restriçóes da natureza. A crise deve constituir uma oportunidade para a economia social e solidária crescer, para questionar as regras económicas vigentes, abrir o debate sobre os objectivos da economia, e para explorar alternativas económicas que superem o exclusivo papel do mercado e do Estado.

A economia social e solidária, em todas as suas modalidades, tem despertado interesse crescente na construção de uma Europa com maior coesão social e solidariedade e desempenha um papel importante na inserção de populaçóes desfavorecidas, pela via do emprego, formação, qualificação profissional e apoio empresarial (criação de postos de trabalho e apoio ao auto-emprego, contratação de serviços prestados por estas populaçóes...), contribuindo para desenvolver as suas potencialidades e participaçáo plena na sociedade, isto é, para a 
sua cidadania. As instituiçóes e organizaçóes da economia social promovem o desenvolvimento social, corrigindo desequilíbrios gerados no mercado de trabalho, aumentando a empregabilidade de indivíduos com formaçóes "socialmente úteis" e de qualidade, face à imprevisibilidade das transformaçóes laborais.

\section{Economia social e solidária - questóes conceptuais e teóricas para um saber e intervenção plural}

A utilização do conceito de economia solidária generalizou-se, face à necessidade de superação da dualidade público/privado e procurando dar respostas à crise do Estado-Providência e à dissolução crescente da solidariedade familiar e comunitária. "Economia solidária", "Economia social", "Terceiro sector", "Sector não lucrativo", "Economia comunitária”, "Economia civil”, "Economia da comunhão"..., designam organizaçóes situadas entre o Estado, o mercado e a comunidade, o social e o económico, tanto nos seus objectivos como nos seus modelos organizacionais. Há dificuldade em estabelecer critérios definidores e claros de economia social e solidária, sendo enorme a abrangência do conceito. A sua definição conceptual e teórica varia de país para país, bem como o seu grau de desenvolvimento e de reconhecimento, devido a factores económicos, históricos, políticos, sociais e culturais (Azam, 2003; Demoustier, 2006). Portugal integra o grupo de países europeus com "maior aceitação do conceito de economia social" (CIRIEC, 2000), a par da França, Itália, Espanha, Bélgica, Irlanda e Suécia.

No "Dicionário Internacional da Outra Economia", Laville e Gaiger agregam as acepçóes do conceito de economia solidária à ideia "de solidariedade, em contraste com o individualismo utilitarista que caracteriza o comportamento económico predominante nas sociedades de mercado" (2009, p. 162). Esta "outra economia” posiciona o princípio da solidariedade no centro da actividade económica e abrange actividades que contribuem para a democratização da economia, a partir de um envolvimento dos cidadãos (Laville, 1999; França Filho \& Laville, 2004).

Favreau e Lévesque (1986, in Paixão, 1998) apontam duas perspectivas teóricas divergentes da economia social. A primeira, baseada nos princípios neo-liberais, entende este sector como um paliativo para a inevitabilidade de exclusão social provocada pelo funcionamento da economia. A economia social visa assegurar uma alternativa de integração para os excluídos do trabalho assalariado. A segunda centra-se na redefinição das relaçóes entre economia e sociedade, procurando revalorizar o poder dos cidadáos e democratizar a economia e a sociedade. A economia social é concebida como uma forma possível de organização económica e abrange actividades económicas que dizem respeito "à sociedade de pessoas que busquem democracia económica associada à utilidade social" (Defourny, 2009, p. 156).

A economia social e solidária representa uma oportunidade para um tipo de sociedade com vocaçáo social, uma nova alavanca potencial da política de emprego, um modo de organização económica alternativo (Lipietz, 2001; Laville, 2009; Nowak, 2010). A economia solidária busca um modelo económico e uma acção pública renovada, obedece a uma lógica distinta da capitalista e não deve alhear-se dos movimentos e dinâmicas sociais alternativos. Diferentes autores defendem que a globalização da economia social fará contrapeso à globalização da economia de mercado (Lautier, 2003; Favreau, 2003; Demoustier, 2004). 
O conceito "economia solidária" abrange elementos como sustentabilidade, defesa do meio ambiente, diversidade cultural, desenvolvimento local, competitividade, governabilidade, eficiência e uma outra mundialização (Ramos, 2011). Ao contrário das actividades económicas baseadas na lógica de mercado e regidas pela competitividade, a economia solidária valoriza a cooperaçáo entre os trabalhadores e preserva um carácter de responsabilidade sócio-ambiental e de consumo consciente. Veja-se, por exemplo, as cooperativas populares, as integradas por trabalhadores na reciclagem de resíduos sólidos e líquidos.

O sector não lucrativo, referido por terceiro sector, economia social, solidária ou sector voluntário, é constituído por diferentes instituições organizadas, sob a forma de associação, fundação, misericórdia, cooperativa, mutualidade, clube,..., prosseguindo variados objectivos. Existem dois tipos de organizaçóes neste sector: as que funcionam como empresas (apesar do objectivo náo ser o lucro, como é o caso das cooperativas) e as que funcionam como instituiçôes de administração privada, financiadas por donativos, quotas, voluntariado e apoios estatais (o caso das IPSS). A economia social abrange o subsector do mercado ou empresarial (cooperativas e mutualidades, grupos empresariais controlados por cooperativas) e o subsector não mercantil (associaçóes, fundações e organizaçóes que fornecem bens e serviços na maior parte gratuitos ou a preços simbólicos).

A Economia Social engloba duas realidades distintas, "ligadas entre si por valores de autonomia e solidariedade social (cidadania): por um lado, a Economia Social, enquanto actividade de suporte social (apoio às franjas desfavorecidas da população ou em processos de exclusão), por outro, a Economia Social como um modelo de actividade económica alternativo ao capitalista, no qual a actividade económica e organizacional respeite os direitos do Homem enquanto ser integral e actue de forma a impossibilitar a geraçáo de exclusão" (Nunes, Reto \& Carneiro, 2001, p. 33). Estes autores caracterizam as organizaçôes da economia social partindo dos seguintes critérios (idem, p. 56): prossecução de fins não lucrativos ou impossibilidade de apropriação dos excedentes pelos associados; prática de uma gestão democrática e participação dos trabalhadores; ênfase na qualidade dos produtos e serviços, em detrimento da margem de lucro; existência de processos formais e sistemáticos de controlo da qualidade; investimento na formação dos trabalhadores, nas suas competências técnicas e organizacionais; aplicação dos excedentes na acção social e seu objectivo primordial de bem-estar ou equilíbrio social; autonomia financeira face ao Estado ou outras entidades, viabilidade económica e, finalmente, a sua natureza jurídica, privada, pública e social.

No Manual da Comissão Europeia, define-se desta forma a economia social: "conjunto de empresas privadas organizadas formalmente, com autonomia de decisão e liberdade de filiaçáo, criadas para servir as necessidades dos seus associados através do mercado, fornecendo bens e serviços, incluindo seguros e financiamentos, e em que a distribuição pelos sócios de eventuais lucros ou excedentes realizados, assim como a tomada de decisóes, não estão directamente ligadas ao capital ou às cotizaçóes dos seus associados, correspondendo um voto a cada um deles. A economia social também inclui empresas privadas organizadas formalmente, com autonomia de decisão e liberdade de filiação, que prestam serviços de "não mercado" a agregados familiares e cujos eventuais excedentes realizados náo podem ser apropriados pelos agentes económicos que as criam, controlam ou financiam” (CIRIEC, 2007, p. 9).

Também em Portugal o conceito de economia social não é muito claro, havendo tendência para incluir, quer organizaçóes com intervenção no mercado, como as cooperativas 
e as mutualidades, quer organizaçóes com fins assistencialistas, como as misericórdias. A Constituição da República Portuguesa, relativamente aos sectores de propriedade dos meios de produção (Art. ${ }^{\circ} 82 .^{\circ}$ ), separa os dois sub-sectores - do cooperativismo e da economia social. A revisão constitucional de 1997 acrescentou uma alínea ao n. ${ }^{\circ} 4$ deste Artigo: "também integram o sector cooperativo e social os meios de produção possuídos e geridos por pessoas colectivas sem carácter lucrativo, que tenham como principal objectivo a solidariedade social, designadamente as entidades de natureza mutualista". Portugal faz parte da "variante mediterrânica" do modelo europeu de economia social, onde coexistem importantes organizaçóes caritativas ligadas à Igreja, com organizaçóes laicas associadas a uma rede cooperativa forte (Archambauld, 2008).

De acordo com o estudo de Franco et al. (2005), o sector náo lucrativo em Portugal, compreende as seguintes modalidades institucionais:

- associaçôes, constituídas por iniciativas de cidadãos, assumindo nalguns casos o estatuto de utilidade pública - associaçóes de consumidores, de defesa do consumidor e de defesa do ambiente, de bombeiros voluntários, ...

- fundações, como forma institucional mais recente, reconhecidas só após a aprovação do código civil de 1867.

- misericórdias, organizaçóes filiadas na Igreja católica e regidas pelo direito civil e pelo direito canónico, a primeira das quais (de Lisboa) foi criada em 1498. Têm objectivos assistenciais e estão organizadas na União das Misericórdias Portuguesas.

- associaçóes mutualistas, de solidariedade social, organizadas sob a forma de estatuto de Instituiçóes Privadas de Solidariedade Social (IPSS) e destinadas a prover assistência mútua aos seus membros e famílias.

- cooperativas, de produçáo ou de consumo, que se regem pelo código cooperativo.

- museus, que, embora muitos deles sejam instituiçóes públicas, estão legalmente reconhecidos como instituiçóes sem fins lucrativos.

- organizaçóes de desenvolvimento local, que actuam principalmente nas zonas rurais e destinadas a apoiar e promover o desenvolvimento local das populaçóes.

- organizaçôes não governamentais, com actividade nos domínios culturais, ambientais, sociais, cívico,..., no âmbito nacional e internacional.

\section{Economia solidária como instrumento de inovaçáo e de empreendedorismo social - práticas de cidadania e de voluntariado}

A inovação social diz respeito a novas estratégias, conceitos, ideias e organizaçóes que respondem a necessidades sociais de todos os tipos - desde as condiçóes de trabalho e de educação até ao desenvolvimento comunitário e à saúde - e que alargam e reforçam a sociedade civil (Costa, 2009). A inovação é uma componente crucial do empreendedorismo social.

Assistimos ao desenvolvimento de iniciativas sócio-económicas que, não sendo da esfera privada nem da iniciativa pública, promovem um novo conceito de empreendedorismo com finalidades sociais. Este insere grupos vulneráveis em iniciativas que adoptam fórmulas empresariais, procurando resultados económicos positivos, mas sem fins lucrativos, e tendo como principal objectivo, além das motivaçôes económicas, a luta contra a exclusão sócio-laboral (Gaiger, 2009) e cuja incidência económica territorial de dimensão micro 
é importante (Portela, 2008; Hespanha, 2009). O empreendedorismo social caracteriza-se por acçóes colectivas onde o objectivo passa por solucionar problemas de cariz social, estando associado ao desenvolvimento de projectos de indivíduos ou de comunidades, não necessariamente envolvidos numa organização, visando alcançar o interesse geral, o bem comum, ou responder a necessidades sociais não satisfeitas. $\mathrm{O}$ empreendedor social cria riqueza enquanto melhora as condiçóes de vida da população e exerce uma actividade empresarial, para benefício público ou social, e não com o intuito do lucro.

Austin et al. (2006) definem empreendedorismo social como uma actividade inovadora de criaçáo de valor social, podendo ocorrer em sectores com fins lucrativos, empresas e governo e desenvolver-se em diferentes esferas (económica, ensino, social e espiritual), com actividades realizadas por indivíduos e organizaçôes, incluindo o sector público, organizações comunitárias, de acção social e instituiçôes de caridade (Weerawardena \& Mort, 2006). O empreendedorismo social, dentro de um contexto de acção social, tem sido visto como agente de mudança social, tanto em áreas de preocupaçáo social como das políticas sociais públicas.

Borzaga e Defourny (2001) destacam, no âmbito do empreendedorismo social, as chamadas "empresas sociais", salientando o seu papel fundamental no reforço da coesão social e económica. Estas empresas apostam no desenvolvimento de novos serviços e actividades diversas, como resposta a situaçóes locais de exclusão social, desemprego e baixos rendimentos e promovem o processo de inclusão social (Vidal, 2005). Uma empresa social tem objectivos primariamente sociais, cujos excedentes são principalmente reinvestidos com essa finalidade na empresa ou na comunidade, não se orientando para a maximização dos lucros dos accionistas ou proprietários.

Portugal tem um sector social importante em crescimento, com várias organizaçóes de apoio social relevantes e, apesar da sua dimensão comparativamente reduzida, tem apostado no empreendedorismo social, onde os protagonistas individuais se sobrepóem, muitas vezes, aos objectivos das próprias organizaçôes. No que respeita a organizaçóes mais estabelecidas, com maior impacto, um exemplo de boas práticas é o Banco Alimentar Contra a Fome, organização de apoio social que conseguiu criar uma economia de escala e gerir bem o seu impacto. Assinale-se a capacidade de organização, de liderança e de comprometimento das mulheres e dos homens portugueses em organizaçóes de voluntariado, sem fins lucrativos, de ordem associativa, organizaçóes pertencendo ao terceiro sector, à economia social e solidária e a contribuiçáo do seu trabalho voluntário e empreendedorismo para o sistema económico e a solidariedade social.

No relatório do CIRIEC (2007), a economia social apresenta-se como "pólo de utilidade social" multidimensional, proporcionando coesão social, desenvolvimento local e regional, inovação e emprego, mas é também fonte de participação democrática e integração social (Noya \& Clarence, 2007). A economia solidária é encarada como espaço privilegiado para a integraçáo social e, consequentemente, para o desenvolvimento social/local/participativo, não só porque promove uma variedade de actividades e serviços úteis à comunidade, nomeadamente os serviços de proximidade, mas também porque abrange parte importante da população com maior dificuldade de inserção laboral e, simultaneamente, os voluntários, que procuram ocupar o seu tempo livre, de acordo com as suas aptidóes ${ }^{1}$.

1 Voluntário é o "indivíduo que de forma livre, desinteressada e responsável se compromete, de acordo com as suas aptidóes próprias e no seu tempo livre, a realizar acçóes de voluntariado no âmbito de uma organização 
Para além de absorver o desemprego originado pela incapacidade do Estado e do sector lucrativo em criar emprego, outro contributo importante da economia solidária é o de reinventar a própria noção de trabalho, através da revalorização do trabalho socialmente útil que náo ocorre estritamente no contexto da relação salarial, como é o caso do trabalho voluntário (Ferrand-Bechmann, 2000; Archambaud, 2002; Anheier, 2003). Trabalham na UE25, mais de 5 milhôes de voluntários a tempo inteiro (CIRIEC, 2007, p. 7), assistindo-se na última década, na União Europeia, a um aumento do número de voluntários e de organizaçóes promotoras do voluntariado. Os maiores níveis de envolvimento são no norte da Europa, o que contrasta fortemente com a realidade dos países europeus do sul, como Portugal, onde foi criada a Confederaçáo Portuguesa de Voluntariado e o Conselho Nacional para a Promoçáo do Voluntariado (CNPV). O ano de 2011 foi designado como ano europeu do voluntariado.

Muitas das organizaçóes da economia social e solidária em Portugal têm forte presença de trabalhadores em regime de voluntariado, bem visível nas associaçóes (de bombeiros voluntários, de desenvolvimento local, desportivas,...), IPSS e fundaçôes, mas também nos partidos, sindicatos, cooperativas, cáritas, mutualidades, misericórdias e organizaçôes sem fins lucrativos que cumprem serviços de apoio e regulação socioeconómica e realizam tarefas com vista à promoção da qualidade de vida, cultura e recreio. Cerca de $70 \%$ das instituiçóes acolheram voluntários, ascendendo aos $100 \%$ nas organizaçóes de escuteiros e das cáritas (Almeida, 2008). Neste inquérito ao voluntariado em Portugal, estimou-se em 360600 os voluntários a colaborar com as instituiçôes, dos quais: 105200 voluntários dos órgãos sociais, 119400 outros voluntários regulares e 136000 voluntários ocasionais. A proporção de voluntários face aos trabalhadores remunerados nas Instituiçóes era a seguinte: cooperativas - 10,7\%; mutualidades - 17,9\%; fundaçóes - 25,9\%; associaçóes em geral - 181,1\%. Segundo Franco et al. (2005), cerca de 30\% dos trabalhadores do sector náo lucrativo em Portugal seriam voluntários.

No Inquérito ao Voluntariado do OEFP, cerca de 60\% das instituiçôes indicaram necessidades de formação específica para voluntários dos órgãos sociais, dos regulares e do responsável pela coordenação de voluntários (Almeida, 2008). Em grande parte das instituiçóes da economia social em Portugal, os líderes são voluntários, tendo as actividades empresariais, profissionais e sindicais essencialmente voluntários nos orgãos sociais, predominando o sexo masculino e obtendo como recompensa, reconhecimento público e social, satisfação pessoal, estatuto e estabelecimento de uma rede de contactos.

$\mathrm{O}$ voluntariado em Portugal atinge valores de envolvimento reduzidos, comparativamente a outros países, nomeadamente do Norte da Europa (Mathou, 2010). Mas apesar da ausência de uma forte cultura de participaçáo cívica e de uma cultura de voluntariado no país, existem dinamismos interessantes de mobilização, sobretudo em campanhas pontuais, como as recolhas de alimentos do banco alimentar e a campanha limpar Portugal, onde o grau de participação tem sido significativo. Quanto às áreas de intervenção, no voluntariado em Portugal, como no sul da Europa, distinguem-se os serviços sociais. Importa definir estratégias locais que considerem as necessidades de voluntários beneficiários e organizaçóes, assim como o acompanhamento e avaliação do voluntariado. Faltam dados

promotora" (Art. ${ }^{\circ} 3^{\circ}$, Lei no 71/98 de 3 de Novembro). Também a ONU define como voluntário "o jovem ou o adulto que, devido ao seu interesse pessoal e ao seu espírito cívico, dedica parte do seu tempo, sem remuneração alguma, a diversas formas de actividades, organizadas ou não, de bem estar social ou outros campos”. 
rigorosos sobre a verdadeira contribuição do voluntariado e do empreendedorismo social, nomeadamente feminino, havendo necessidade de registar actividades, funçôes e cargos ocupados por mulheres e homens e também de formar para o voluntariado.

\section{Responsabilidade social - uma via para a inovação, a solidariedade e a sustentabilidade}

As expressôes de "responsabilidade social", "coesão social" e "cidadania empresarial" referem uma realidade que ganha importância e desperta responsabilidades alargadas na comunidade empresarial, traduzindo a noção de que a liberdade de competir e obter lucros tem de ser acompanhada da obrigação de ser socialmente responsável. A responsabilidade social empresarial é a forma de gestão que se define pela relação ética e transparente da empresa com os públicos com que se relaciona e pelo estabelecimento de metas empresariais compatíveis com o desenvolvimento sustentável da sociedade, preservando recursos ambientais e culturais para geraçóes futuras, respeitando a diversidade e promovendo a redução das desigualdades sociais.

Se as responsabilidades individuais e empresariais ganham espaço crescente de intervenção, não se trata, porém, de optar entre responsabilidade social do Estado e responsabilidade social das empresas ou dos cidadãos e de desvincular as instâncias políticas das suas responsabilidades ou deixar supor que o mercado pode remediar sozinho as suas imperfeiçóes.

No Livro Verde da Comissão Europeia "Promover um quadro europeu para a responsabilidade social das empresas" (2001), esta é definida como "um conceito segundo o qual as empresas decidem, numa base voluntária, contribuir para uma sociedade mais justa e para um ambiente mais limpo. (...). Esta responsabilidade manifesta-se em relação aos trabalhadores e, mais genericamente, em relação a todas as partes afectadas pela empresa e que, por seu turno, podem influenciar os seus resultados" (parágrafo 8). O Livro Verde remete-nos para duas dimensóes da responsabilidade social empresarial: a dimensão interna diz respeito aos trabalhadores e, nomeadamente, ao investimento no capital humano, gestão dos recursos humanos, saúde e segurança no trabalho, gestão e adaptação à mudança (critérios de reestruturaçôes), gestáo do impacto ambiental e dos recursos naturais; a dimensão externa incide sobre comunidades locais, parceiros comerciais, fornecedores e consumidores, autoridades públicas e ONG, direitos humanos e preocupaçóes ambientais.

A necessidade de construir a Europa Social exige formação ao nível da responsabilidade social, em diferentes dimensóes: aprendizagem ao longo da vida; empregabilidade activa; prevenção de riscos profissionais; promoção e desenvolvimento sustentado; eco-eficiência; diálogo social; respeito e promoção de um ambiente saudável.

Competitividade e responsabilidade social reforçam-se mutuamente nas modernas estratégias empresariais, sendo múltiplas as vantagens das empresas que compatibilizam melhoria da performance económica e da performance social (Porter \& Kramer, 2006; Orlitzly, 2008): imagem e reputação melhoradas junto da comunidade; colaboradores mais satisfeitos e motivados para enfrentar novos desafios de competitividade; maior produtividade e sustentabilidade; melhoria das competências de gestão; capacidade acrescida de resistência a crises conjunturais.

O desenvolvimento crescente das preocupaçóes éticas nas empresas leva-as a justificar os seus meios de acção e a finalidade das suas actividades e a assumir responsabilidades em relação aos 
seus membros e à sociedade (Ballet \& Bry, 2001; Pesqueux \& Biefnot, 2002; Ramos, 2005; Capron \& Quairel, 2010). Alguns sinais nesse sentido são visíveis em empresas mercantis, integrando códigos de conduta ética, finalidades de solidariedade social, equilíbrio ecológico e ambiental, empresas solidárias para a aplicação ética de fundos de pensóes e outras aplicaçóes e bancos concedendo crédito às populaçóes desfavorecidas (Amouroux, 2003). As empresas preocupam-se com os impactos gerados no macroambiente em que se inserem, constituindo-se agentes do desenvolvimento económico e social (Ramos, 2003): criando riqueza e emprego, dispensando formação, desenvolvendo acçóes sociais, educativas e culturais, participam na vida da sociedade, envolvendo-se na luta contra o desemprego e a exclusão, a solidariedade em relação aos mais desprotegidos, a inserçáo de jovens e desempregados de longa duração, a melhor afectação do território. Estas acçôes melhoram a qualidade de vida, a educação e o bem-estar das colectividades locais. Algumas empresas disponibilizam funcionários para acçóes de interesse social, orientam estágios e apoiam actividades circum-escolares, organizam acçôes de voluntariado, nas áreas da acção social e da protecção ambiental.

No nosso país e na Europa têm surgido iniciativas em favor do investimento responsável e da aceitação voluntária de princípios básicos de ética empresarial. No nosso país, o Conselho Económico e Social aprovou um parecer neste domínio, em 2003, e esta preocupação aparece nas Estratégias Europeias para a Inclusão, assim como no número crescente de empresas que entram em parcerias, no âmbito de programas de luta contra a exclusão social e de iniciativas de desenvolvimento local, contribuindo para uma economia mais inclusiva e solidária (OECD, 2003). Veja-se o caso do GRACE (Grupo de reflexão e apoio à cidadania empresarial), organizaçáo sem fins lucrativos, criada em 2000, com objectivos de reflexão, promoção e desenvolvimento de iniciativas de responsabilidade social empresarial, entre as quais a do voluntariado.

A divulgação de boas práticas de gestão empresarial, em áreas distintas como acção social, educação, cultura, desporto, ambiente, saúde, ciência, constitui um objectivo das organizaçóes promotoras: facilitar a prática do voluntariado pelos trabalhadores e desenvolver programas que envolvam também os familiares; patrocinar projectos de interesse social, cultural, ambiental; promover formaçáo junto de públicos desfavorecidos; apoiar instituiçóes sem fins lucrativos; negociar parcerias com organizaçóes não governamentais, visando implementar projectos de cidadania empresarial. Ser socialmente responsável é cada vez mais uma vantagem competitiva e faz parte de uma gestão de excelência, onde existem valores de qualidade e inovação.

Os valores e as atitudes morais e éticas dos cidadãos são parte integrante da cidadania e da economia, social e solidária, com responsabilidades sociais, ao serviço da justiça, do bem-estar de todos e do desenvolvimento (Bartoli, 2003; Sen, 2003). É importante analisar as relaçóes entre a ética, a economia e a responsabilidade. Para estes autores, a economia e a sua visão mecanicista e positivista, encontra-se consideravelmente empobrecida pelo seu distanciamento relativamente à ética, apelando a uma nova visão da economia e da empresa, na qual se integre devidamente a dimensão social, isto é, o papel que a empresa desempenha na economia e na sociedade, e assuma a responsabilidade ético-política daí decorrente.

\section{O microcrédito como instrumento de inovaçáo, de coesáo e de responsabilidade social}

No mundo desenvolvido, os modelos de microcrédito estão associados à responsabilidade social. Alvord et al. (2004) referem processos e tecnologias que promovem o bem-estar 
social, criando assim inovaçóes sociais, como o caso do Grameen Bank, um sistema de microcrédito para empresários pobres que não teriam possibilidade de aceder a um banco comercial. A inclusão social, através do microempreendedorismo social, é um dos grandes objectivos do microcrédito. Na concepção do Grameen Bank, o banco da aldeia, que tem no economista bengali Yunus, prémio Nobel da Paz, em 2006, a sua principal referência, o microcrédito traduz uma realidade complexa e pressupóe um mecanismo formal ou semi-formal de prestação de serviço de crédito, uma forma alternativa de garantir o acesso aos mais carenciados (Yunus, 2010).

A ideia do Grameen Bank expandiu-se mundialmente (Attali et al., 2007), sendo o microcrédito encorajado na União Europeia e pelo Parlamento Europeu (2009), aprovando-se, em Julho de 2009, a criação de uma Estrutura de Microfinanças Europeia para o Emprego e a Inclusão Social. Por toda a Europa estáo a melhorar as perspectivas de tornar o microcrédito um instrumento eficaz de políticas sociais, adaptando este modelo oriundo de países em desenvolvimento, como mostra o "Handbook of microcredit in Europe: social inclusion through microenterprise development" (Carboni, 2010). Constituirá a crise financeira actual uma oportunidade para o desenvolvimento do microcrédito?

$\mathrm{O}$ microcrédito tem um papel importante no combate à pobreza, à exclusão social e ao desemprego, contribuindo para o desenvolvimento económico local e a melhoria da vida das pessoas, com uma multiplicidade de iniciativas geradoras de rendimentos (Johnson \& Rogaly, 1997; Guérin \& Vallat, 1999). O sucesso das experiências de microcrédito, deve-se a vários factores (Gibbons, 1999): relaçóes próximas entre o banco e os clientes; capacidade de chegar aos pobres; imagem do banco transmitida pelos técnicos; envolvimento das mulheres; reforço das capacidades das comunidades e grupos locais; promoção do bem-estar através da criação de microempresas e da cooperaçáo de entre-ajuda tradicionais. A sua eficácia baseia-se em acreditar que os pobres e os socialmente excluídos, sem possibilidades de recurso às oportunidades de crédito na banca, podem desenvolver um pequeno negócio e criar o seu próprio posto de trabalho, mediante a atribuição de um pequeno empréstimo, sem garantias, concedido na base da confiança nas pessoas, nas suas capacidades e responsabilidades (Evers et al., 2007; Nowak, 2010). O microcrédito possibilita assim aos cidadãos desfavorecidos, a participação nos mecanismos económicos integradores e a participação cidadã, afirmando o crédito como direito humano fundamental, tal como outros direitos, não só formais, mas efectivos, de que todos devem usufruir (Sen, 2003).

Em Portugal, o microcrédito não constitui ainda um importante mecanismo de integração social das populaçóes excluídas, mas em conjunto com outras políticas activas de emprego, tem um potencial inovador para desenvolver o empreendedorismo e o micro-empresariado em populaçóes com dificil integração sócio-profissional, reforçando o seu rendimento familiar, empowerment e autoestima. Desde 1998, ano da criação da Associação Nacional de Direito ao Crédito (ANDC), foram concedidos empréstimos a pessoas que puderam iniciar a sua própria actividade económica e criar postos de trabalho, sendo a taxa de retorno dos empréstimos elevada (Mendes, 2007). Trata-se, essencialmente, de pequenos negócios de produção de bens ou prestação de serviços: limpezas, pequenos comércios, costura, reparaçóes domésticas, restauração, vestuário, artesanato...

$\mathrm{O}$ microcrédito tem tido um crescimento rápido nos últimos anos, o que confirma a sua pertinência e a sua capacidade de dar resposta a necessidades náo satisfeitas. 
Dados sobre microcrédito da Associaçáo Nacional de Direito ao Crédito (ANDC) 1999 a 2011

Creditados 1954 projectos de investimento, viabilizando-se a criação de 2021 postos de trabalho.

$52,6 \%$ dos microempresários são mulheres.

Processos aprovados: Lisboa - 38,6\%; Norte - 24,1\%; Centro - 21,0\%; Alentejo - 10,4\%; Algarve $5,9 \%$.

$34,9 \%$ dos projectos situam-se no grupo etário entre 25 e 35 anos, 28,5\% entre 35 e 45 anos e 18,6\% entre 45 e 55 anos.

Habilitaçôes literárias dos microempresários: 30,1\% ensino secundário; $22,6 \%$ - $3^{\circ}$ ciclo; $14,5 \%$ - 2o ciclo; $13,7 \%$ - $1^{\circ}$ ciclo; $12,4 \%$ - ensino superior.

86,7\% dos microempresários são portugueses, 7,4\% são originários de África e 2,8\% da América.

Distribuiçấo dos projectos por actividades: $37,6 \%$ - comércio por grosso e a retalho; $13,6 \%$ - alojamento, restauraçáo e similares; $12,8 \%$ - outras actividades de serviços; $10,4 \%$ - indústria transformadora; 4,9\% - construção.

Fonte: ANDC

A ANDC trabalha em parceria com diferentes pessoas e instituiçóes: voluntários que se quotizam para financiar a associação; instituições financeiras que concedem créditos aos microempresários, seleccionados pela Associação; organismos públicos que implementam medidas de luta contra o desemprego e a exclusão (IEFP); instituiçóes locais próximas das populaçóes; organizaçóes estrangeiras congéneres, nomeadamente no quadro da Rede Europeia de Microfinanças. É importante articular o trabalho da ANDC com outras instituiçôes de economia solidária, com as autarquias locais e serviços públicos de promoção do emprego e acção social, no sentido de desenvolver parcerias e aprofundar o trabalho em rede, dinamizando o desenvolvimento local e sensibilizando os técnicos para identificar potenciais microempresários e agentes de desenvolvimento no terreno.

Quando se apela cada vez mais à ética e responsabilidade social empresarial, a aplicação em fundos destinados a financiar microprojectos é um instrumento pertinente, para a inclusão social, sobretudo dos mais desfavorecidos. Os modelos de intervenção do microcrédito podem ser implementados ao nível das micro e pequenas organizaçóes do terceiro sector. Os "banqueiros solidários" constituem um grupo profissional que se autonomiza progressivamente da profissão de banqueiro clássico, ocupando um espaço de cruzamento entre a finança, a banca e o trabalho social (Moulévrier, 2010). Seria desejável que os organismos financeiros revissem o seu paradigma de desenvolvimento e as suas práticas, de forma a integrar a economia solidária como componente incontornável do desenvolvimento sustentável.

\section{Necessidade de fomentar a inovaçáo e a formaçáo no microempreendedorismo e na economia solidária}

Há necessidade de maior esforço de sensibilização da classe empresarial, nomeadamente ao nível da inovação e formação, nas pequenas e médias empresas (PME), carenciadas de formação profissional na área dos recursos humanos. Uma das razóes do atraso tecnológico da indústria portuguesa tem sido o baixo nível de qualificação dos empresários/gestores (dois terços tem apenas a formação primária ou secundária), das chefias intermédias, assim como dos recursos humanos disponíveis. A reduzida escolaridade da população activa 
constitui um forte limite aos esforços intensivos de formação profissional, tendo a educação impactos importantes nas oportunidades de vida e níveis de rendimento, nas dinâmicas de mobilidade social dos trabalhadores, nos padróes de crescimento e mudança estrutural das economias. Face às crescentes transformaçóes, várias prioridades se colocam à formação profissional (Ramos, 2003, 2007): - articular o conteúdo dos sistemas de ensino e formação profissional às necessidades do mercado de trabalho; fornecer orientaçáo profissional ao longo da vida e sistemas de acreditação de níveis de educação e formação profissional que conjugem ensino formal com aprendizagem náo formal; possibilitar o acesso dos trabalhadores mais velhos à formação profissional, aprendizagem de novas competências e obtenção de qualificaçóes necessárias à empregabilidade; facilitar o acesso à formação profissional das mulheres que desejem reintegrar o mercado de trabalho; aplicar programas de formação destinados a aumentar a empregabilidade dos jovens e de outros grupos desfavorecidos; desenvolver planos de formação profissional contínua na economia social e nas pequenas e médias empresas.

A actuação do Estado, através de políticas dirigidas aos empresários e trabalhadores, contribui para a formação, o desenvolvimento económico e a coesão social, nomeadamente nas micro, pequenas e médias empresas (MPE), que constituem a maioria do tecido empresarial português e possuem elevada taxa de criação de emprego.

Políticas de intervençáo para as MPE

\begin{tabular}{|c|c|}
\hline \multicolumn{2}{|c|}{ Estado-Politicas } \\
\hline $\begin{array}{c}\text { EMPRESÁRIOS } \\
\text { Formação gestionária } \\
\text { Educação para a cidadania } \\
\text { Associativismo e parcerias } \\
\text { Participação cívica }\end{array}$ & $\begin{array}{c}\text { TRABALHADORES } \\
\text { Inserção social } \\
\text { Educação para a cidadania } \\
\text { Formação profissional/Qualificação } \\
\text { Associativismo sindical } \\
\text { Participaçáo cívica }\end{array}$ \\
\hline $\begin{array}{c}\text { GESTÃO SUSTENTADA E MODERNIZADA } \\
\text { CIDADANIA EMPRESARIAL }\end{array}$ & $\begin{array}{l}\text { EMPREGABILIDADE } \\
\text { CIDADANIA }\end{array}$ \\
\hline
\end{tabular}

Fonte: Guerreiro (2001), cit. in Ramos, 2007, p. 314

O modelo empresarial português é pouco propício a uma cultura da inovaçáo (Ramos, 1997), sendo necessário inovar na implementação de políticas activas de formação e emprego, na melhoria das qualificações e garantia de empregabilidade através do desenvolvimento da formação ao longo da vida (Ramos, 2007). A cidadania plena realiza-se pelo acesso às oportunidades e liberdades económicas e políticas que o desenvolvimento oferece aos membros da sociedade, entre as quais: oportunidades de educação e de saúde; apoio à procura de emprego e ao desenvolvimento de actividades por conta própria; aumento do empreendedorismo e da empregabilidade; acesso à formação, qualificação profissional, níveis de rendimento e poder de compra elementares. A exclusão social implica privação, falta de recursos ou ausência de cidadania, isto é, a participação na sociedade, aos diferentes níveis (cultural, económico, político e social) (Sen, 2003; Costa, 2008). A educaçáo é um 
campo estratégico fundamental para o desenvolvimento das práticas de cidadania (Ramos \& Gonçalves, 2005).

Não existe um modelo de gestão do terceiro sector, ou está longe de ser aplicado de forma generalizada. O modelo de empreendedorismo e de gestáo da economia convencional não responde às necessidades específicas da economia solidária, nomeadamente de formaçâo organizacional e de gestão, centrando-se na liderança operacional e de topo, visando a viabilização e modernização das organizaçóes. São poucas as instituiçóes a valorizar a formação contínua e quando esta existe, é essencialmente dirigida aos funcionários, o que é muito redutor, dado que, como assinalam Nunes, Reto e Carneiro (2001), há uma baixa escolaridade dos dirigentes deste sector, tornando necessário que a formação contínua os tenha também como alvo. Há exemplos de boas práticas, como a ligação existente entre o comércio justo e a formação dos artesãos do Sul, assim como com a escolarização dos seus filhos (Vergès, 2006). Nos países do Norte, o acento é posto na formação dos benévolos e na educação do grande público, em particular dos jovens.

Nas organizaçóes da economia social e solidária, aparece como pertinente a promoçáo de acçóes de gestão e formação profissional: apoio à valorização de competências profissionais locais e à inovaçáo e eficiência nos processos de trabalho; formação para activos do sector, ou que possam vir a ser integrados profissionalmente; programas de modernizaçáo e profissionalização dos métodos de gestáo. Torna-se necessário apoiar iniciativas empresariais na economia solidária, colocando-se desafios à profissionalizaçáo dos agentes de mudança que são os empreendedores sociais e os microempresários.

\section{O potencial de emprego na economia solidária, nomeadamente nos serviços de proximidade}

A Uniāo Europeia reconhece as potencialidades da economia social na diminuição do desemprego e no desenvolvimento local, criando a acção-piloto "terceiro sistema e emprego" (Cimeira do Luxemburgo, 1997). Assinale-se a Resolução do Parlamento Europeu sobre economia social (2009), "pedra angular do modelo social europeu”, e a criaçáo em Portugal, em 2010, do Conselho Nacional para a Economia Social (CNES).

Existem dificuldades de informação estatística sobre economia social e solidária nos Estados membros da União Europeia (UE). A União estima ser possível criar postos de trabalho, com base em necessidades locais não satisfeitas, em sectores como serviços de proximidade, recuperação e reciclagem de materiais, reordenamento da fauna, reabilitação e protecção dos meios naturais, ecoturismo e recuperação do património urbano. Segundo um estudo para a Comissão Europeia, sobre o terceiro sector e o emprego, a economia social (cooperativas, mutualidades e associaçóes) empregava cerca de 9 milhóes de pessoas a tempo inteiro na $\mathrm{UE}^{2}$, isto é, $9 \%$ do emprego civil assalariado, para além de incorporar um volume significativo de trabalho voluntário (CIRIEC, 2000, p. 25). O relatório "A economia social na União Europeia" (CIRIEC, 2007) assinalava, na UE25, mais de 240 mil cooperativas em diferentes actividades (agricultura, intermediação financeira, sector retalhista e alojamento, indústria, construção e serviços), empregando directamente 3,7

2 As associaçóes fornecem a grande maioria (71\% dos empregos), seguido das cooperativas (25,7\%) e das mutualidades $(3,1 \%)$. 
milhóes de pessoas e envolvendo mais de 143 milhóes de filiados. Ultrapassa 120 milhôes, o número de pessoas assistidas por mutualidades ao nível da saúde e da segurança social, tendo as mútuas seguradoras uma quota de mercado de $23,7 \%$. Se ao sector cooperativo juntarmos outras iniciativas da economia social (associaçóes, fundaçóes e organizações afins), os valores ascendem a 11 milhóes de pessoas empregues, equivalente a $7 \%$ da população activa da União Europeia.

Em Portugal, saliente-se igualmente a capacidade empregadora desta economia (Ramos, 2011): as IPSS empregariam mais de 71 mil pessoas, incorporando também trabalho de cariz voluntário; as cooperativas ocupavam mais de 51 mil trabalhadores, sendo em maior número as cooperativas agrícolas, de habitação e construção e as de serviços; as misericórdias empregariam mais de 17 mil trabalhadores e as mutualidades 4 mil; as fundaçóes apresentam objectivos significativos nas áreas da solidariedade social, educação e ciência. Em 2008, existiam mais de 3 mil cooperativas em Portugal, representando 5\% do PIB (INSCOOP/CASES). Segundo um estudo realizado com a Universidade Johns Hopkins, a economia social era responsável por $4,2 \%$ da população activa em Portugal, valor abaixo da média dos países desenvolvidos (7,4\%) (Franco et al., 2005, resultados do "Comparative nonprofit sector Project").

A grande maioria do emprego nas áreas da acção social é ocupada por mulheres, sendo importante a sua contribuição voluntária informal. Assinale-se a condicionante mão-de-obra qualificada, sendo o ensino básico o nível de habilitação predominante, e muitos dos empregos no terceiro sector serem precários e informais (o ganho médio deste sector de acção social é, em média, inferior ao do conjunto da economia). Demoustier (2001) refere a instabilidade do emprego na economia social e solidária, devido à dificuldade em profissionalizar os trabalhadores (nomeadamente, os voluntários) e à instabilidade de programas e financiamentos.

Nos serviços de proximidade e à comunidade a economia solidária tem possibilidades de crescer. Na Europa, estes serviços contribuiram para o desenvolvimento da economia solidária, cruzando necessidades tradicionais (serviços de apoio pessoal e social) e outras: serviços ao domicílio; serviços de natureza doméstica prestados no exterior; pequenas reparaçóes domésticas; segurança e vigilância; transportes individuais ou colectivos; ordenamento de espaços públicos urbanos; produtos e serviços culturais ligados a identidades locais; formas alternativas de turismo; protecçáo ambiental, formas de poupança de energia. Os serviços de proximidade englobam "actividades que se inserem no âmbito das funções tradicionalmente asseguradas pela família, no espaço doméstico, e que, uma vez transferidas para a esfera pública, mantêm uma experiência de proximidade relacional entre prestador e utente" (Feio, 2000, p. 17). Certos autores identificam os serviços de proximidade como "serviços de solidariedade" (Cette et al., 1993): ajuda a pessoas idosas, dependentes, jovens em dificuldade, guarda de crianças, apoio escolar, ajuda à segurança de bens e pessoas e à melhoria do habitat, transportes locais, serviços ligados ao ambiente, serviços de lazer e cultura, comércio de proximidade.

Os serviços de proximidade aumentaram como "subsector", respondendo a necessidades que o Estado não consegue colmatar, no âmbito da oferta pública de serviços sociais e "muito para além da economia social e dos serviços sociais, na sua forma clássica, obrigam-nos a pensar a sua estruturação aliada às questôes da qualidade, da profissionalização, da capacidade de inovar e flexibilizar respostas" (Evaristo, 1999, p. 84). As ofertas deste sector enquadram-se "em pequenas iniciativas empresariais ou na esfera da economia social; têm 
subjacente uma lógica localista, isto é, de proximidade, estando, por isso, associados a iniciativas e à problemática do desenvolvimento local” (idem, p. 83).

Desde 1995, a Comissão Europeia propõe a utilização das "novas jazidas de emprego" na promoção de iniciativas empresariais e criação de empregos no desenvolvimento local. A identificação de jazidas de emprego ou de nichos de mercado resulta da existência de oportunidades tecnológicas e de necessidades de mercado náo satisfeitas ou insuficientemente satisfeitas (Greffe, 1990). No trabalho de Centeno e Abrantes (2000, p. 24), os serviços de proximidade são identificados dentro de 5 áreas, como 24 jazidas de emprego:

- serviços da vida quotidiana: serviços domésticos, cuidado e guarda de crianças, novas tecnologias da informação e comunicação, assistência a jovens com dificuldades; serviços de melhoramento do nível de vida: melhoria e manutenção de habitaçôes, serviços de segurança, de transportes públicos locais, revitalização de áreas públicas urbanas, desporto, comércio local; serviços culturais e recreativos: turismo, sector audiovisual, património cultural, desenvolvimento cultural local; serviços do ambiente: gestão de lixos, da água, protecção e conservação de áreas naturais, monitorização e controlo da poluição, poupança de energia; densificação e aumento da competitividade dos tecidos económicos locais e regionais: prestação de serviços de consultoria a PME, formação profissional, serviços de design industrial, de marketing, biotecnologias.

A economia solidária demonstra capacidade para corrigir deficiências no domínio dos serviços de bem-estar, tais como, serviços sócio-culturais, denominados por serviços de proximidade. Os empregos associados necessitam de ser valorizados pela via do estatuto laboral e pelo acesso a formação adequada. A dinâmica dos serviços à colectividade, dos serviços sociais e dos serviços pessoais é uma realidade crescente das economias mais desenvolvidas, constituindo parte integrante da terciarização e da criação de emprego nos países europeus e da OCDE. Os planos nacionais de emprego portugueses (1999 a 2008-2010), nas linhas directrizes para o emprego emanadas da Estratégia Europeia para o Emprego, apelam à economia social, identificando três domínios de intervenção: inserção no mercado de trabalho de grupos desfavorecidos (população com deficiência, minorias étnicas, imigrantes); promoção de acçōes de formação no sector cooperativo através de incentivos fiscais; promoçáo da criação de emprego no quadro regional e local.

\section{Economia solidária em favor do desenvolvimento local e dos laços sociais e comunitários}

Actualmente, a preocupação das políticas sociais centra-se no local, na territorialidade de medidas, na negociação de direitos e objectivos com os actores sociais, na participação destes, na criação de parcerias activas locais e rentabilização de recursos, face ao desenvolvimento social. A análise das formas de descentralização das políticas sociais exige maior conhecimento dos processos de globalização, mas também de desenvolvimento local. $\mathrm{Na}$ problemática do desenvolvimento local sustentável, há que satisfazer necessidades essenciais e qualidade de vida, economia e emprego, inclusão social, organizaçôes democráticas e administração territorial, que evite o êxodo das populaçôes (Ramos \& Gonçalves, 2006). O desenvolvimento local está assim associado a processos de melhoria das condiçôes de vida num determinado território, mas também à aplicação de uma pedagogia da participação das pessoas que aí vivem, ao exercício de uma cidadania activa, como eixo central 
dos processos de desenvolvimento. Por inerência, o conceito de endogeneidade está ligado à noçáo de empowerment (Friedmann, 1996), apontando a necessidade da participação democrática no processo de desenvolvimento local.

Também Melo (2002, p. 517) considera que "olhar o Desenvolvimento como um fenómeno essencialmente determinado a partir de baixo implica assumir a importância de factores como o envolvimento dos actores locais nos processos de decisão, a mobilização local dos recursos produtivos do território, a valorização dos factores e dos bens e serviços produzidos localmente, os processos de criação ou difusão da inovação, os ganhos emergentes de uma melhor coordenaçáo local de iniciativas, o aumento do valor acrescentado retido localmente, a internalizaçáo territorial dos efeitos de transbordo (spill-over) positivos das iniciativas públicas e privadas".

O processo de desenvolvimento participativo proposto pelas entidades da economia solidária envolve a comunidade e a participação igualitária ao nível do desenvolvimento local. As iniciativas locais de desenvolvimento social e emprego dinamizam a economia solidária, em domínios como os serviços de proximidade ou "serviços de solidariedade" e a recuperação do património urbano. Para a execução destas metas, contribuíram um conjunto de instrumentos enquadrados no mercado social de emprego (escolas-oficinas; programas e actividades ocupacionais; empresas de inserção) e algumas outras medidas de formação e de apoio ao microcrédito (Ballet, 1997; Ramos, 2003, 2005).

O mercado social de emprego (MSE) constituiu um instrumento promotor do emprego, do reforço da cidadania e potenciador de maior coesão social, no combate ao desemprego, pobreza e exclusão social, respondendo a necessidades sociais não satisfeitas pelo funcionamento normal do mercado, com os seguintes princípios: aprofundamento do espírito de parceria; estímulo à dinamização sócio-local; promoção da capacidade de auto-sustentação económica; qualidade dos serviços prestados; relevância social das actividades desenvolvidas; reforço de competências pessoais, sociais e profissionais dos desempregados abrangidos; promoção da empregabilidade de pessoas com possibilidades reduzidas, no sistema formal de emprego; criação adicional de postos de trabalho (Jorge, 2000; CMSE, 2001). A expansão do MSE beneficiou de novas formas organizativas e de uma intervenção estatal integrando áreas sócio-económicas tradicionais e formas locais específicas, com desafios à reestruturação do Estado-Providência e sua articulação territorial, constituindo o território um importante espaço de participação e de inovação. Em toda a Europa, as acçôes em matéria de emprego e formação das colectividades territoriais aumentaram fortemente, desde meados dos anos 70 do século XX (Greffe, 1988). A proposta "iniciativas locais de emprego", da OCDE, no final dos anos 80, assumiu importante papel na definição de políticas europeias de combate ao desemprego, à pobreza e exclusão social.

É visível a ligação entre economia social e desenvolvimento comunitário, sendo este "assente numa perspectiva de valorização das comunidades locais e das suas aspiraçôes e capacidades" (Amaro, 2009, p. 108). As associaçóes de desenvolvimento local procuram melhorar as condiçôes de determinada localidade, passando as suas acçóes, nomeadamente, pela requalificação social e urbana e por programas de estímulo ao emprego. A economia solidária procura uma perspectiva territorializada de acção e de promoção do desenvolvimento local e sustentável, aproveitando os recursos endógenos do espaço onde se insere e as sinergias com outras actividades económicas, havendo uma simbiose entre os conceitos de desenvolvimento local e de economia solidária (Demoustier, 2004), que mobiliza igualmente as dinâmicas sócio-económicas extra-europeias (Revue Tiers Monde, 2007). 
Às organizaçôes da economia social, atribuem-se as funçôes de promoçâo da coesão social e económica e de uma cultura de participação cívica, esperando-se que a concretização destas funçôes desencadeie, ao nível das comunidades locais, diferentes impactos positivos: maior capacidade empresarial e criação de emprego; inovação em actividades diversas (ambiente, lazer...); consolidação de novas competências, alargando as fontes locais de aquisição de conhecimentos inovadores e melhorando as condiçôes de empregabilidade; prestação de serviços adequados às necessidades locais e meios acessíveis às comunidades, para maior equidade no acesso a serviços socialmente úteis; novas possibilidades de participação cívica e de maior autonomia face a instituiçôes e formas de regulaçáo do Estado e do mercado (Ferrão, 2000; Neves, 2000).

A economia solidária promove a coesão social, ao fomentar a implicação e participação social e a cultura democrática ao nível local e territorial, bem como a capacidade de "distribuição e redistribuição de rendimentos e riqueza de forma mais justa do que a empresa capitalista tradicional" (Chaves \& Monzón in CIRIEC, 2000, p. 140). As organizaçóes desta economia contribuem para o reforço da identidade local e têm potencial para colmatar desigualdades sociais e económicas e, simultaneamente, fomentar o desenvolvimento endógeno de base local e territorial, cada vez mais valorizado face às fragilidades territoriais incutidas pela globalização e aos problemas económicos, sociais, culturais, ambientais e políticos dela resultantes.

Nos objectivos das organizaçóes da economia social e solidária, há uma preocupação crescente, relativamente aos valores democráticos de igualdade, partilha e cidadania e, também, com a melhor utilização dos recursos locais e o desenvolvimento económico, político e social integrado. Um dos eixos de intervençáo das políticas de emprego passa pelo desenvolvimento da economia social e do terceiro sector, através do estabelecimento de parcerias na implementaçáo de políticas sociais activas. Tais parcerias, entre o Estado e a sociedade civil, envolvem actores de serviços públicos (Administração Central e Autarquias) e organizaçốes não governamentais (IPSS, Associaçôes locais e de desenvolvimento local e outras) e assentam em complementaridades e articulaçóes das respectivas competências em matéria de inclusão social, intervenção territorial e partilha de responsabilidades, na detecção dos problemas e nas soluçôes encontradas.

\section{Consideraçóes finais}

Há dificuldades em estabelecer critérios definidores de economia social e solidária e insuficiente informação estatística sobre o chamado terceiro sector. A economia social coloca o princípio da solidariedade, da gratuidade e da dádiva no centro da actividade económica, e a democratização da economia a partir do envolvimento dos cidadáos, sendo apresentada como uma solução para os défices de cidadania, por parte das instâncias oficiais, nomeadamente do Estado-Providência. As organizaçóes da economia social e solidária procuram outras formas de organização do trabalho, conjugando utilidade e solidariedade. Para além de absorverem o desemprego, outro contributo importante é o de revalorizarem o trabalho socialmente útil, como o voluntariado, e também o de fomentarem a entreajuda social, a mutualização e o mecenato.

É de referir, na inclusão social, o papel das empresas, vinculadoras de valores e práticas sociais, as quais, assumindo uma gestão empresarial com responsabilidades sociais e reco- 
nhecendo as necessidades dos intervenientes na sociedade, avaliando as consequências das suas acçóes no plano social, melhoram o bem estar das populaçóes. Um projecto integral de economia solidária articula-se com outros movimentos de promoção de actividades económicas solidárias, tais como finanças solidárias, empreendedorismo social, empresa social, comércio justo. Referimos o importante papel da cidadania empresarial, responsabilidade ética empresarial e finanças solidárias, nos domínios da formação, qualificação profissional, criação de emprego e inclusão social, contribuindo para o desenvolvimento económico, social, cultural e ambiental da comunidade. Apoiar as instituiçóes da economia solidária significa valorizar um importante instrumento de inclusão e acção social, um potencial de empregabilidade, de coesão, de cidadania, de desenvolvimento local e comunitário, com possibilidades de crescimento, especialmente nos serviços de proximidade ou "serviços de solidariedade" e à comunidade.

$\mathrm{Na}$ economia solidária, existem necessidades formativas de gestão, de formação profissional e de promoção dos recursos humanos, impondo-se o investimento na qualificação das organizaçóes da economia solidária, na qualidade dos bens produzidos e dos serviços prestados, na melhoria da qualificação dos recursos humanos e na garantia de empregabilidade: valorizar os empregos pela via do estatuto laboral e pelo acesso a formação adequada; desenvolver acçôes de educação e formação dos trabalhadores, incluindo a área do voluntariado; modernizar as estruturas de gestáo das organizaçôes; formar técnicos ao nível do desenvolvimento organizacional e qualidade da gestão e da formação vocacionada para a abordagem holística da cultura organizacional e profissional.

Há necessidade de inovar na implementação de politicas activas de formação, emprego e empreendedorismo, desenvolver serviços de proximidade, reforçar laços sociais e comunitários, criar novas parcerias entre o Estado e a sociedade civil, consentâneas com a Estratégia Europeia para o Emprego, no sentido de aprofundar a solidariedade, a participaçáo, o empowerment e o desenvolvimento social e local.

Qual o papel reservado à economia social? Uma economia, como ciência moral, ética e política, não pode ignorar a busca de um modelo económico comprometido com a justiça social e uma acção pública renovada. A sedimentação de uma economia social e solidária não é apenas de importância económica, mas também ética e política, procurando uma abordagem alternativa da economia e admitindo uma pluralidade de paradigmas e de princípios de comportamento económico. A economia solidária coloca desafios e oportunidades de inovação social no repensar uma nova articulação entre Estado, sociedade civil e mercado, catalizando recursos para uma utilidade social que não ignore exigências de rentabilidade económica e competitividade, mas valorize a promoção do emprego e do desenvolvimento sustentável. Terá que se salvaguardar que não contribui para a (des) responsabilização do Estado nas funções que lhe são inerentes. Apesar da sua importância, a economia solidária/social não é uma realidade estabilizada e os seus contornos, assim como o seu futuro, estáo em aberto, questionando-se o impacto da actual conjuntura internacional recessiva neste sector. 


\section{Referências Bibliográficas}

Almeida, M. A. (Coord.) (2008). Estudo sobre o voluntariado. Lisboa: OEFP. www.oefp.pt

Amaro, R. R. (2009). Desenvolvimento local. In A. D. Cattani et al. (Coord.) Dicionário internacional da outra economia (pp. 108-113). Coimbra/São Paulo: Almedina/CES.

Amouroux, Ph. (2003). La finance solidaire pour un autre projet de société. Revue du MAUSS, 21, 66-72.

Attali, J. \& Arthus-Bertrand, Y. (2007). Voyage au cour d'une révolution. La microfinance contre la pauvreté. Paris: Ed. JC Lattès.

Anheier, H. K. et al. (2003). Work in the non-profit sector: forms, patterns and methodologies. Geneva: OIT.

Anheier, H. K. \& Bem-Ner, A. (Eds.) (2003). The study of the nonprofit enterprise: theories and approaches, New York: Academic/Plenum.

Archambault, E. (2002). Le travail bénévole en France et en Europe. Revue Française des Affaires Sociales, vol. 56, 4, 13-39.

Archambault, E. (2008). L'économie sociale en France dans une perspective européenne, Working Paper CIRIEC, no 4.

Austin, J. et al. (2006). Social and commercial entrepreneurship: same, different or both? Entrepreneurship: theory and practice, vol. 30, 1, 1-22.

Azam, G. (2003). Économie sociale, tiers secteur, économie solidaire, quelles frontières? Revue du MAUSS, 21, 151-161.

Ballet, J. (1997). Les entreprises d'insertion. Paris: PUF.

Ballet, J. \& Bry, F. de (2001). L'entreprise et l'éthique. Paris: Le Seuil "Points".

Bartoli, H. (2003). Repensar o desenvolvimento: acabar com a pobreza. Lisboa: Instituto Piaget.

Bartoli, H. (2003). Ethique et économie: médiation du politique. Paris: UNESCO.

Borzaga, C. \& Defourny, J. (Eds.) (2001). The emergence of social enterprise. London: Routledge.

Borzaga, C. \& Tortia, E. (2006). Worker motivations, job satisfactions, and loyalty in public and nonprofit social services. Nonprofit and Voluntary Sector Quarterly, 35, 225-248.

Capron, M. \& Quairel-Lanoizelée, F. (2010). La responsabilité sociale d'entreprise, Paris: La Découverte.

Carboni, B. Jayo et al. (2010). Handbook of microcredit in Europe. Cheltenham: Edward Elgar Publishing.

Castles, F. (2004). The future of the welfare state: crisis myths and crisis realities. Cambridge: Polity Press.

Centeno, L. \& Abrantes, C. (2000). Identificação de potenciais nichos de mercado e jazidas de emprego. Lisboa: MTS, OEFP.

Centro Internacional de Pesquisa e Informação sobre a Economia Pública, Social e Cooperativa (CIRIEC) (2000). As empresas e organizaçōes do terceiro sistema - um desafio estratégico para o emprego. Lisboa: INSCOOP.

Centro Internacional de Pesquisa e Informação sobre a Economia Pública, Social e Cooperativa (CIRIEC) (2007). A economia social na União Europeia. Comité Económico e Social Europeu.

Cette, G. et al. (1993). Nouveaux emplois de services - les 10 services de solidarité. Futuribles, 174, 5-26.

Comissão Europeia (2001). Promover um quadro europeu para a responsabilidade social das empresas. Livro Verde. Bruxelas (COM-2001-366).

Comissão para o Mercado Social de Emprego (Org.) (2001). Mercado Social de Emprego: Encontro nacional de interlocutores. Comunicaçōes. Lisboa: MTS/DPP.

Costa, A. B. (Coord.) (2008). Um olhar sobre a pobreza. Vulnerabilidade e exclusão social no Portugal contemporâneo. Lisboa: Gradiva.

Costa, J. (Coord.) (2009). Inovação social, Cadernos Sociedade e Trabalho, XII, Lisboa: MTSS/GEP.

Crane, A., McWilliam, A., Matten, D., Moon, J. \& Siegel, D. (Eds.) (2008). Oxford handbook of corporate social responsability. Oxford: Oxford University Press.

Defourny, J. (2009). Economia Social. In A. D. Cattani et al. (Coord.) Dicionário internacional da outra economia (pp. 156-161). Coimbra/São Paulo: Almedina/CES.

Demoustier, D. (2001). L'économie sociale et solidaire - s'associer pour entreprendre autrement. Paris: Syros.

Demoustier, D. (Org.) (2004). Economie sociale et développement local, Paris: L'Harmattan.

Demoustier, D. et al. (2006). Débats autour de la notion d'économie sociale en Europe. RECMA Revue Internationale de l'Économie Sociale, 300, 8-18.

Esping-Andersen, G. (2002). Why we need a new welfare state. Oxford University Press.

Evaristo, T. (1999). Emprego e formação no âmbito dos serviços de proximidade. Sociedade e Trabalho, 5, 81-90.

Evers, J., Lahn, S. \& Jung, M. (2007). Status of microfinance in Western Europe - an academic review. EMN Issue Paper, Paris: EMN.

Favreau, L. (2003). L'économie sociale et solidaire: pôle éthique de la mondialisation ? Paris: UNESCO.

Feio, P. A. (Coord.) (2000). Serviços de proximidade. Caracterização e perspectivas de evolução. Lisboa: IEFP.

Ferrand-Bechmann, D. (2000). Le métier de bénévole. Paris: Anthropos/Economica. 
Ferrão, J. (2000). Economia social, comunidades locais e transferibilidade de informaçáo, conhecimentos e soluçóes. Sociedade e Trabalho, 8/9, 22-27.

Ferreira, S. (2005). O que tem de especial o empreendedor social? O perfil de emprego do empresário social em Portugal, Oficina do CES, 223.

274 França Filho, G. Carvalho \& Laville, J. L. (2004). Economia Solidária. Porto Alegre: UFRGS.

Franco, R. C. (Coord.) (2005). O sector não lucrativo português numa perspectiva comparada. Universidade Católica Portuguesa e Johns Hopkins University.

Friedmann, J. (1996). Empowerment - uma politica de desenvolvimento alternativo, Oeiras: Celta Editora.

Gaiger, L. I. (2007). A outra racionalidade da economia solidária. Revista Critica de Ciências Sociais, 79, 57-77.

Gaiger, L. I. (2009). Empreendimento económico solidário. In Cattani et al. (Coord.) Dicionário internacional da outra economia (pp.181-187). Coimbra/São Paulo: Almedina/CES.

Gibbons, D. S. (1999). Grameen Bank: manual de formaçâo para a reprodução internacional do sistema financeiro do Banco Grameen no Combate à Pobreza. Lisboa: ACEP.

Greffe, X. (1988). Décentraliser pour l'emploi: les initiatives locales de développement. Paris: Economica.

Greffe, X. (1990). Nouvelles demandes, nouveaux services. Paris: La Documentation Française.

Greffe, X. (2002.). Le développement local, Paris: Ed. de L'Aube- DATAR.

Guérin, I. \& Vallat, D. (1999). Exclusion et finance solidaire: le cas français, Économie et solidarités, vol. 30, 1, 95-110.

Hespanha, P. (2009). Microempreendedorismo. In A. D. Cattani et al. (Coord.) Dicionário Internacional da Outra Economia (pp. 248-254). Coimbra/São Paulo: Almedina/CES.

Jeantet, T. (1999). L'économie sociale européenne Paris: CIEM; (2002). A economia social europeia. Lisboa: ed. Poseidon/Montepio Geral.

Johnson, S. \& Rogaly, B. (1997). Microfinance and poverty reduction. Londres: Oxfam.

Jorge, G. (2000). O mercado social de emprego em Portugal: caminhos percorridos na promoção do emprego e no reforço da cidadania. Sociedade e Trabalho, 11, 7-18.

Lautier, B. (2003). Les limites de l'économie informelle comme alternative à la mondialisation libérale. Revue du MAUSS, 21, pp. 198-214.

Laville, J. L. (1999). Une troisième voie pour l'emploi. Paris: Desclée de Brouwer.

Laville, J. L. (2009). Economia plural. In A. D. Cattani et al. (Coord.) Dicionário Internacional da Outra Economia (pp. 145-149). Coimbra/São Paulo: Almedina/CES.

Laville, J. L. (2010). The solidarity economy. Economic Sociology_the european electronic newsletter. vol. 11, 3, $25-32$.

Laville, J. L. \& Gaiger, L. I. (2009). Economia solidária. In A. D. Cattani et al. (Coord.) Dicionário Internacional da Outra Economia (pp. 162-168). Coimbra, São Paulo: Almedina/CES.

Laville, J-L.; Magnen, J.-Ph ; Filho, G. Carvalho França \& Medeiros, A. (Eds.) (2005). Action publique et économie solidaire. Une perspective internationale, Erès.

Lipietz, A. (2001). Pour le tiers secteur. L'économie sociale et solidaire: pourquoi et comment. Paris: La Découverte/ La Documentation Française.

Mathou, C. (2010). Volunteering in the European Union, London: GHK.

Melo, J. P. B. (2002). A problemática e as políticas de desenvolvimento local. In J. S. Costa (Coord.). Compêndio de Economia Regional (pp. 515-521). Coimbra: APDR.

Ministério do Trabalho e da Solidariedade Social. Plano Nacional de Emprego. (vários anos). ENPSIS - Estratégia Nacional para a Proteç̧ão Social e Inclusão Social. Portugal 2008-2010. Lisboa : MTSS.

Moulévrier, P. (2010). Les "banquiers solidaires" ou la légitimation d'une "profession économique ". Formation - Emploi, 111, 51-64.

Neves, A. O. (2000). Reflexôes de base - Seminário Desenvolvimento local, cidadania e economia social. Sociedade e Trabalho, 8/9, 41-48.

Nowak, M. (2010). L'espoir économique. De la microfinance à l'entrepreneuriat social: les ferments d'un monde nouveau. Paris: Ed. Jean Claude Lattès.

Noya, A. \& Clarence, E. (Eds.) (2007). The social economy: building inclusive economies. Paris: OECD.

Nunes, F., Reto, L. \& Carneiro, M. (2001). O terceiro sector em Portugal: delimitação, caracterização e potencialidades. Lisboa: INSCOOP.

OCDE (2003). The nonprofit sector in a changing economy. Paris: OCDE.

OECD (2008). Growing unequal? Income distribution and poverty in OECD countries. Paris: OECD. (http:// www.oecd.org/els/social /inequality)

O'Kelly, Kevin, P. (2010). Strengthening social cohesion. Improving the situation of low-income workers. Empowerment of people experiencing extreme poverty. Strasbourg: Council of Europe. 
Orlitzly, M. (2008). Corporate social performance and financial performance. A research synthesis. In A. Crane et al. (Eds.) (2008). Oxford handbook of corporate social responsibility (pp. 113-134). Oxford: Oxford University Press.

Paixão, M. T. (1998). Economia social e criação de emprego. Sociedade e Trabalho, 2, 14-21.

Parlamento Europeu (2009). Relatório de 29 de Janeiro de 2009 sobre a iniciativa europeia para o desenvolvimento do microcrédito em prol do crescimento e do emprego. (http://www.europarl.europa.eu)

Parlamento Europeu (2009). Resolução do Parlamento Europeu sobre a economia social. (2008/2250 (INI)), 19 de Fevereiro de 2009.

Pecqueur, B. \& Zimmermann, J. B. (coord.) (2004). Économie de proximité. Paris: Hermès-Lavoisier.

Pesqueux, Y. \& Biefnot, Y. (2002). L'éthique des affaires: management par les valeurs et responsabilité sociale. Paris: Éditions d' Organisation.

Portela, J. (Coord.) (2008). Microempreendedorismo em Portugal. Experiências e perspectivas. Lisboa: INSCOOP.

Porter, M. E. \& Kramer, M. R. (2006). Strategy and society. The link between competitive advantage and corporate social responsibility. Harvard Business Review, vol. 84, 12, 78-92.

Ramos, M. C. P. (1997). Innovation and promotional employment strategies. In Soares, O. D. D. et al. (eds.). Innovation and technology - strategies and policies (pp. 233-254). Kluwer Academic Publisher: Doldrecht, London, New York.

Ramos, M. C. P. (2003). Acção Social na Área do Emprego e da Formação Profissional, Lisboa: ed. Universidade Aberta, (2a ed. 2005).

Ramos, M. C. P. (2005). Economia Social, Inclusão e Responsabilidade Social Empresarial. Revista Investigação e Debate em Serviço Social, 15, no especial, Maio, Porto, 133-175.

Ramos, M. C. P. (2007). Aprendizagem ao longo da vida. Instrumento de empregabilidade e integração social. Revista Portuguesa de Pedagogia, ano 41, 3, nº especial, "Educação e Formação de Adultos", 299-333.

Ramos, M. C. P. (2008). Training, employment and new competences for a sustainable development. Review of International Comparative Management, 9, vol. 2, 15-32.

Ramos, M. C. P. (2009). Questions de l'environnement et contemporanéité. Contemporanea - Revista de Comunicação e Cultura - vol. 7, 1, 1-24 http://www.portalseer.ufba.br/index.php/contemporaneaposcom/article/ view/3601/2669

Ramos, M. C. (2011). Economia solidária, plural e ética, na promoção do emprego, da cidadania e da coesão social. Revista Laboreal, 7, (1), pp. 81-104, http://laboreal.up.pt/revista/artigo.php?id=48u56 oTV658223533894:245552

Ramos, M. C. P. \& Gonçalves, M. O. B. (2005) Espaços de Cidadania - do Local ao Global. pp. 267-276 Contributos para a Educação. In Lemos, E. Sande (Coord.) Ensinar Geografia na Sociedade do Conhecimento, Lisboa: Associação de Professores de Geografia.

Ramos, M. C. P. \& Gonçalves, M. O. B. (2006). Mobilité Géographique et Développement Local au Portugal. In Colloque International Population et Travail - Dynamiques Démographiques et Activités, Associação Internacional dos Demógrafos de Lingua Françesa (AIDELF), Universidade de Aveiro, 18-22/09/2006 (www.aidelf.org), 15 p.

Revue Française des Affaires Sociales (RFAS) (2002). Le bénévolat, vol. 56, 4, Paris: La Documentation Française.

Revue Tiers Monde (2007). Economie solidaire : des initiatives locales à l'action publique, 190, Paris: Armand Colin.

Revue Tiers Monde (2009). La microfinance est-elle socialement responsable?, 197, Paris: Armand Colin.

Salamon, L. M. \& Dewees, S. (2002). In search of the nonprofit sector: improving the state of art. American Behavioral Scientist, 45, 1716-1740.

Santos, B. S. (Org.) (2003). Produzir para viver : os caminhos da produção não capitalista, Porto: ed. Afrontamento.

Schepers, C. et al. (2005) How are people of the non-profit sector motivated ? A research need. Nonprofit Management \& Leadership, 16, 191-208.

Sen, A. (2003). Desenvolvimento como liberdade. Lisboa: Gradiva.

Theuvsen, L. (2004). Doing better while doing good: motivational aspects of pay-for-performance effectiveness in non-profit organizations. Voluntas: International Journal of Voluntary and Nonprofit Organizations, 15(2), 117-136.

Vergès, F. (2006). Le commerce equitable, vecteur de formation et d'éducation. Mondes en développement, tome 34, 2006/2, 134, pp. 95-102.

Vidal, I. (2005). Social enterprise and social inclusion: social enterprise in the sphere of work integration. Journal of Public Administration, 28, pp. 807-825.

Yunus, M. (2008). Criar um mundo sem pobreza - O negócio social e o futuro do capitalismo. Lisboa: Difel.

Yunus, M. (2010). What is microcredit? http://www.grameen-info.org/index.php?option=com_content\&task= view\&id=28\&Itemid $=108$.

Weerawardena, J. \& Mort, G. S. (2006). Investigating social entrepreneurship: a multidimensional model. Journal of world business, vol. 41, 1, 21-35. 
Série Documentos

Imprensa da Universidade de Coimbra

Coimbra University Press

2011

- U

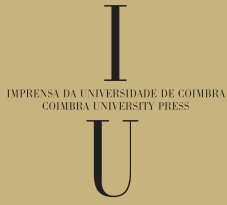

